\title{
Cutis marmorata teleangiectatica congenita
}

\section{Cutis marmorata teleangiectatica congenita} CSOMA ZSANETT RENÁTA DR. ${ }^{1}$, KEMÉNY LAJOS DR. ${ }^{1}$, NAGY DÓRA DR. ${ }^{2}$, SZABÓ HAJNALKA DR. ${ }^{2}$, TÁLOSI GYULA DR. ${ }^{2}$

\author{
SZTE ÁOK Szent-Györgyi Albert Klinikai Központ, Bőrgyógyászati és Allergológiai \\ Klinika ${ }^{1}$, Szeged
}

SZTE ÁOK Szent-Györgyi Albert Klinikai Központ, Gyermekgyógyászati Klinika és Gyermek Egészségügyi Központ ${ }^{2}$, Szeged

\section{ÖSSZEFOGLALÁS}

A cutis marmorata teleangiectatica congenita (CMTC) ismeretlen etiológiájú, igen ritka, sporadikus, általában már születéskor fennálló kapilláris malformáció, amely az érintett bőrterület jellegzetes, márványszerú, retikuláris rajzolatával, esetenként a bör atrophiájával, teleangiectasiával, phlebectasiával társul. Az esetek túlnyomó többségében benignus kórképról van szó, a börtünetek spontán javulást mutathatnak. A CMTC azonban társulhat számos minor és major fejlödési rendellenességgel, illetve több, súlyos, központi idegrendszert és egyéb szervet érintő szindróma részjelensége is lehet, emiatt nagyon fontos az érintett újszülöttek alapos klinikai kivizsgálása és nyomon követése.

A szerzók egy koraszülött és egy érett újszülött esetét ismertetik. A 32. hétre született koraszülött fiúgyermek születésekor a jobb felsố végtagon, a kézfejen, a csuklón, az alkaron, a törzs jobb oldalán, a has és a hát ugyancsak jobb oldalán szegmentális lokalizációban elhelyezkedö kékes-vöröses márványszerü, reticularis rajzolat jelenlétét észlelték, tágult felszínes vénákkal, teleangiectasiával, helyenként atrophiás börterületekkel. A 38. gesztációs hétre született leány újszülött születésekor, a teljes bal alsó végtag laterális részén, szegmentális lokalizációban egy sávszerü területen belül finom elemü, reticularis rajzolatfokozódás, számos tágult felszínes véna és teleangiectasia volt látható. A klinikai tünetek alapján mindkét esetben CMTC diagnózisa merült fel. Az újszülöttek részletes kivizsgálása során egyéb belszervi eltérés, társuló fejlödési rendellenesség nem igazolódott. A gyermekek rendszeres ellenôrzése a Börgyógyászati és Allergológiai Klinika Gyermekbörgyógyászati Szakren-

\section{SUMMARY}

Cutis marmorata teleangiectatica congenita (CMTC) is a very rare, sporadic, congenital capillary malformation of unknown etiology, presenting as a characteristic reticulated blue-violet cutaneous vascular network, associated with teleangiectasia, phlebectasia, atrophy and rarely ulceration. The prognosis of CMCT is generally good, with a tendency to spontaneous improvement of the lesions, but it can be associated with various minor and major developmental abnormalities, and genetic disorders with severe neurologic and other systemic anomalies. Careful consideration of the medical history and a detailed and comprehensive physical examination and evaluation are recommended to exclude associated anomalies with regular follow-up of the affected children.

Patient 1 was a premature baby born at 32 weeks of gestation and referred to the Neonatal Intensive Care Unit at the Department of Pediatrics. Physical examination revealed a reticulated vascular cutaneous network with dilated superficial veins and teleangiectasia, associated with localized mild cutaneous atrophy, involving the right hand, wrist and forearm, and the right side of the trunk. Patient 2 was a mature girl born at 38 weeks of gestation, who exhibited a fine reticular vascular network with marked telangiectasia and a marbled appearance on the lateral aspect of the left lower extremity, in a segmental pattern, with a mild leg circumference discrepancy. The typical clinical signs led to the diagnosis of CMCT in both neonates. The result of detailed physical and systemic examinations of the cardiological, neurological and opthalmological systems were normal and did not reveal any associated anomalies. Both infants are regularly

Levelező szerző: Dr. Csoma Zsanett Renáta, SZTE ÁOK Bőrgyógyászati és Allergológiai Klinika, 6720 Szeged, Korányi fasor 6. email: csoma.zsanett@med.u-szeged.hu 
delésén, valamint a Gyermekgyógyászati Klinika és Gyermek Egészségügyi Központ Kardiológiai Szakrendelésén történik.

\section{Kulcsszavak: cutis marmorata teleangiectatica congenita - újszülött - fejlődési rendellenességek}

\section{Esetismertetés}

\section{1. eset}

Az újszülött az édesanya 2. terhességéből, a 32. gesztációs hétre, 1930 gramm születési súllyal, abruptio placentae miatt sectio caesareával, Apgar 5-7-8 státuszban született. Az anyai anamnézisben gesztációs diabetes mellitus szerepelt. Az újszülöttet születését követôen átszállították az SZTE ÁOK Gyermekgyógyászati Klinika és Gyermek Egészségügyi Központ Perinatális Intenzív Centrumába, ahol 35\%-os oxigénnel gépi lélegeztetés indult. Mellkas röntgen vizsgálat I. stádiumú RDS-nek megfelelő képet írt le. INSURE (intubálás, surfactant, extubálás) kezelésben részesült, majd 25\%-os oxigénnel nasalis BiPAP (Bi-level Positive Airway Pressure) kezelés indult. Állapota stabilizálódott, a nasalis BiPAP, majd CPAP (Continous Positive Airway Pressure) kezelését 4 nap után le lehetett állítani. Az enterális táplálást fokozatosan emelkedő adagokban jól tolerálta. 2 napon át emelkedett szérum bilirubin szint miatt kék fény kezelésben részesült. Anaemia miatt egy alkalommal transzfúziót kapott.
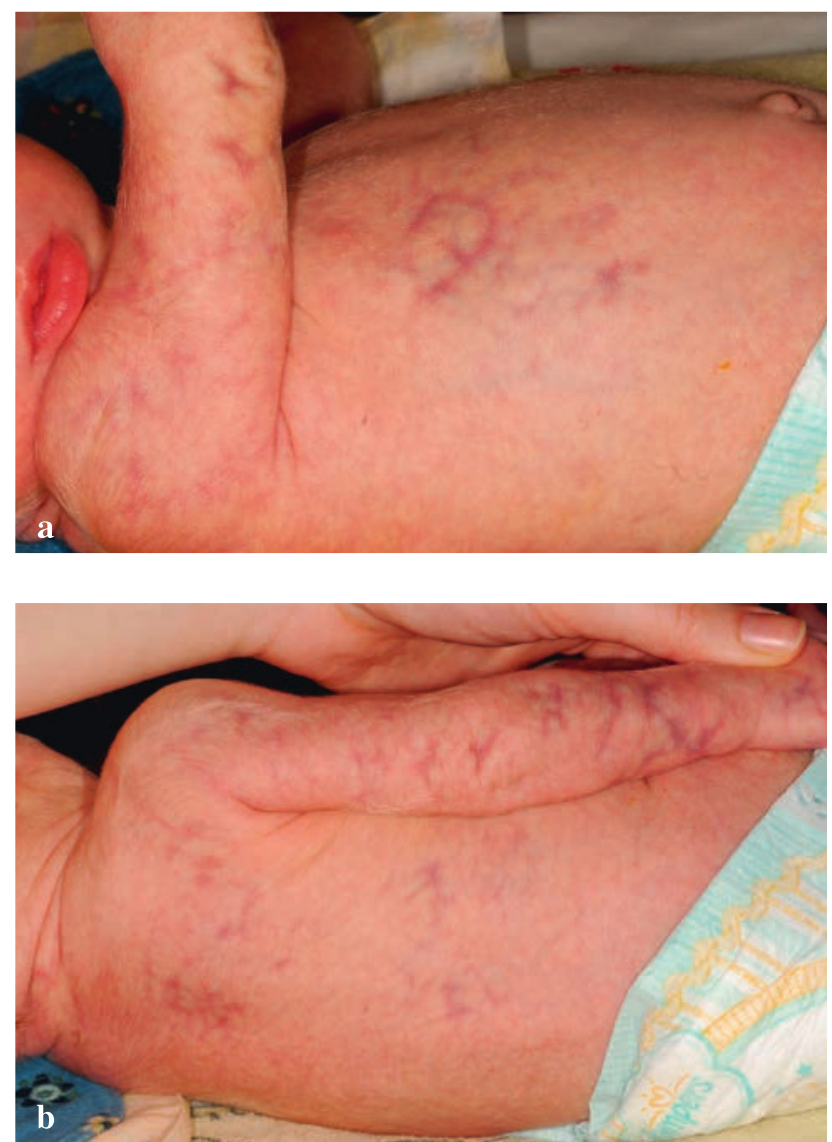

1a., b. ábra

3 napos életkorban a jobb felső végtagon,

a mellkas, a has és a hát jobb oldalán vöröses-lilás színú márványozott, retikuláris rajzolatfokozódás, tágult felszínes vénák, teleangiectasia volt megfigyelhető followed up in the Pediatric Dermatology Outpatient Clinic at the Department of Dermatology and Allergology, and in the Pediatric Cardiology Outpatient Clinic at the Department of Pediatrics.

\section{Key words: cutis marmorata teleangiectatica congenita - neonate - developmental abnormalities}

A bőrgyógyászati szakvizsgálat során a jobb kézfej, alkar, valamint a hát és a mellkas jobb oldalán lilás színú retikuláris rajzolat, tágult felszínes vénák, teleangiectasia, mérsékelt atrophia volt meg-
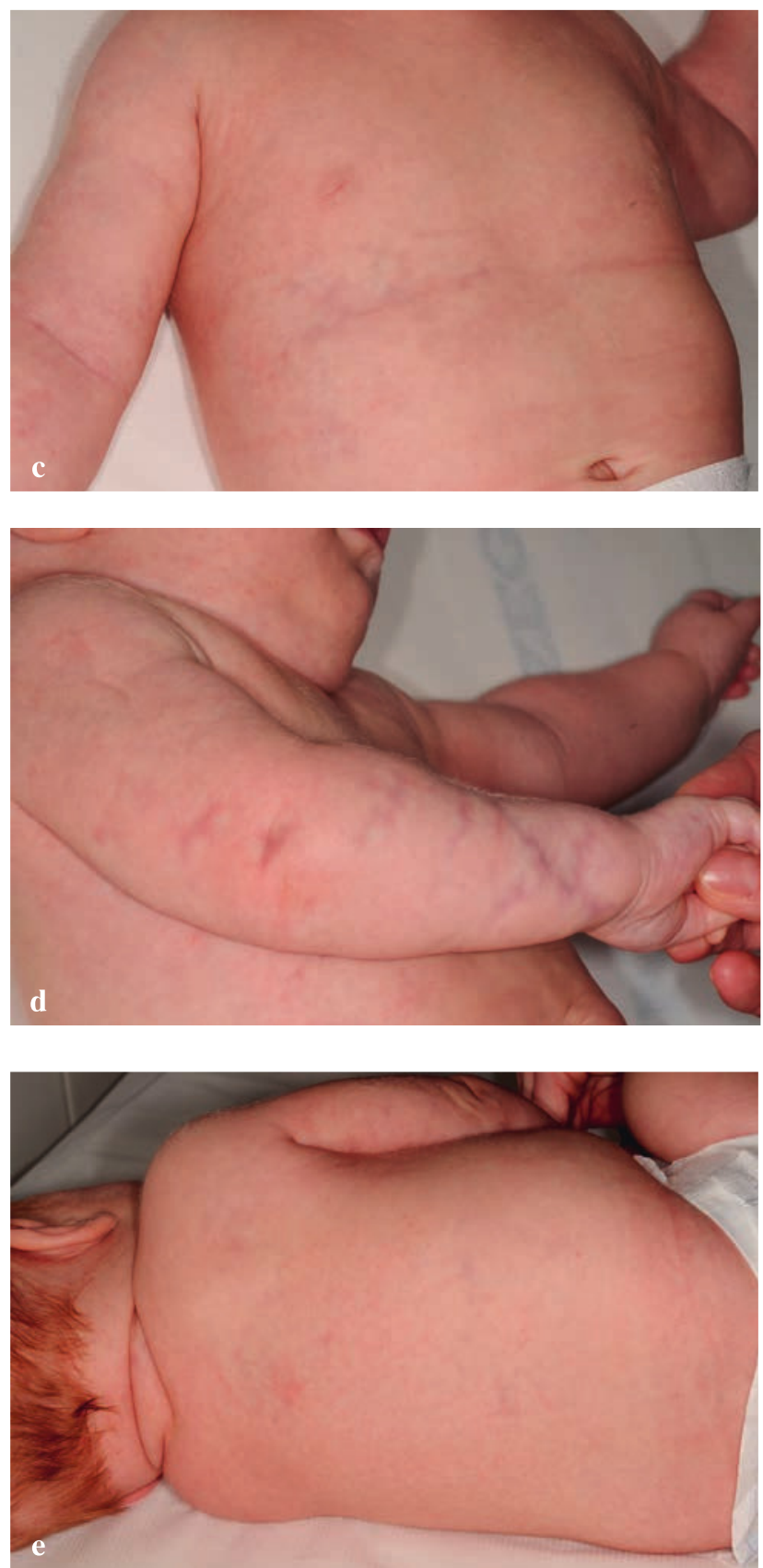

1c-e. ábra

4 hónapos korban

a tünetek jelentős fokú regressziója volt észlelhető mind a felső végtag, mind a törzs területén 
figyelhetô. A jobb felső végtag az ellenoldalihoz képest hypotrophiásnak bizonyult. A típusos klinikai kép alapján CMTC diagnózisát állítottuk fel, szövettani vizsgálat elvégzésére nem került sor. A koponya és a hasi ultrahang vizsgálat, valamint a szemészeti szakvizsgálat kóros eltérést nem igazolt, dysmorphiás jegyeket, egyéb fejlődési anomáliákat nem észleltünk. Kardiológiai kivizsgálása során a Doppler ultrahang vizsgálat foramen ovale apertumot, jelzett mitrális insufficientiát, pici bal-jobb shunttel járó ductus Botalli persistenst igazolt. A családban hasonló bőrtünet nem fordult elő. Négy hetes életkorban, jó általános állapotban került sor hazabocsátására. A gyermek kontrollvizsgálata a Bốrgyógyászati és Allergológiai Klinika Gyermekbőrgyógyászati Szakrendelésén, valamint a Gyermekgyógyászati Klinika és Gyermek Egészségügyi Központ Kardiológiai Szakrendelésén történik. A négy hónapos korban elvégzett kontroll vizsgálat során a bőrtünetek jelentős fokú regresszióját tapasztaltuk (1.a-e. ábra).

\section{2. eset}

Az újszülött 38. gesztációs hétre, 3550 gramm születési súllyal, ismeretlen Apgar-statusban, sectio caesareával jött világra. Kiemelést követôen nem sírt fel, AMBU ballonos lélegeztetést igényelt. Az SZTE ÁOK Gyermekgyógyászati Klinika és Gyermek Egészségügyi Központ Perinatális Intenzív Centrumába légköri oxigén mellett cardiorespiratorikusan stabil állapotban érkezett. Belszervi státuszában fizikális vizsgálattal halk systolés szívzörej volt hallható. A

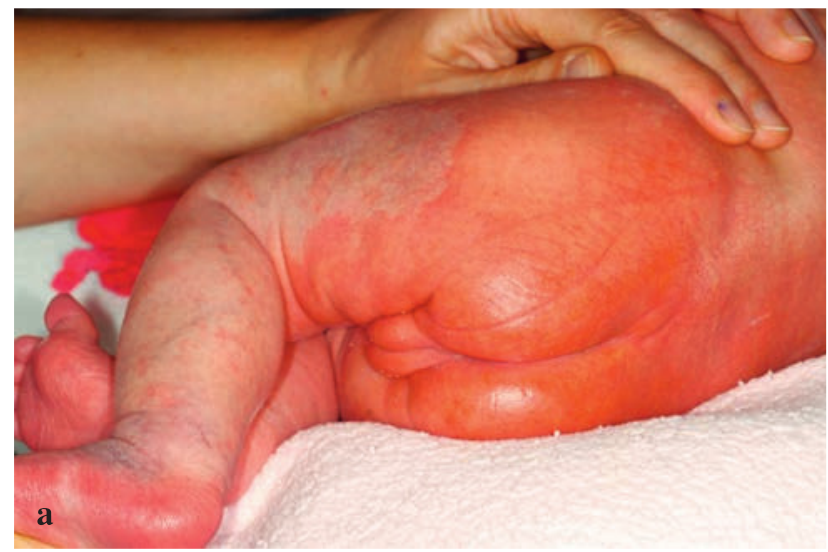

\section{2a. ábra}

Két napos életkorban a bal alsó végtag laterális részén, szegmentális lokalizációban egy sávszerű területen belül finom elemú, reticularis rajzolatfokozódás, számos tágult felszínes véna és teleangiectasia volt látható

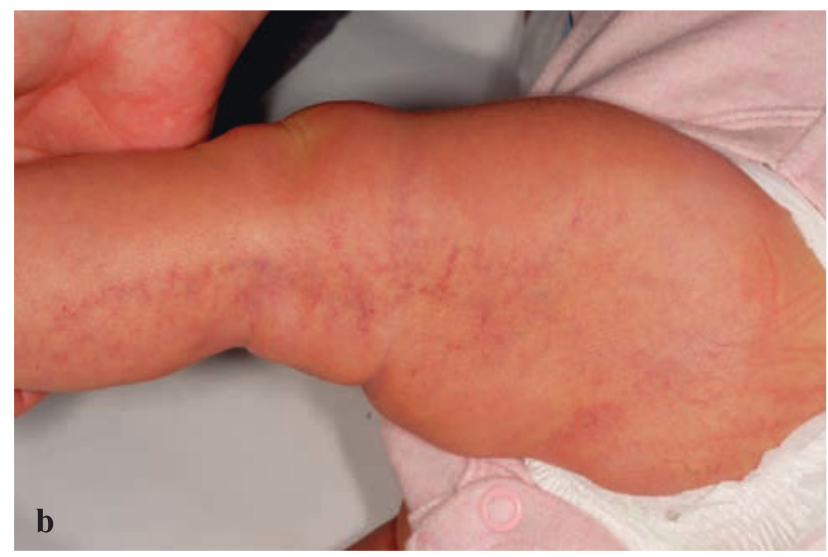

2b. ábra

A két hónapos korban végzett kontroll vizsgálat során lényeges változás nem volt észlelhető a fizikális státuszban bal alsó végtag laterális részén, szegmentális lokalizációban egy sávszerú területen belül finom elemú, reticularis rajzolatfokozódás, számos tágult felszínes véna és teleangiectasia volt látható. Az alsó végtagok között hőmérsékleti különbség nem volt. Doppler ultrahang vizsgálat keringési zavar fennállását nem igazolta. Obszervációja során a bal comb átmérôje konzekvensen nagyobb volt, de

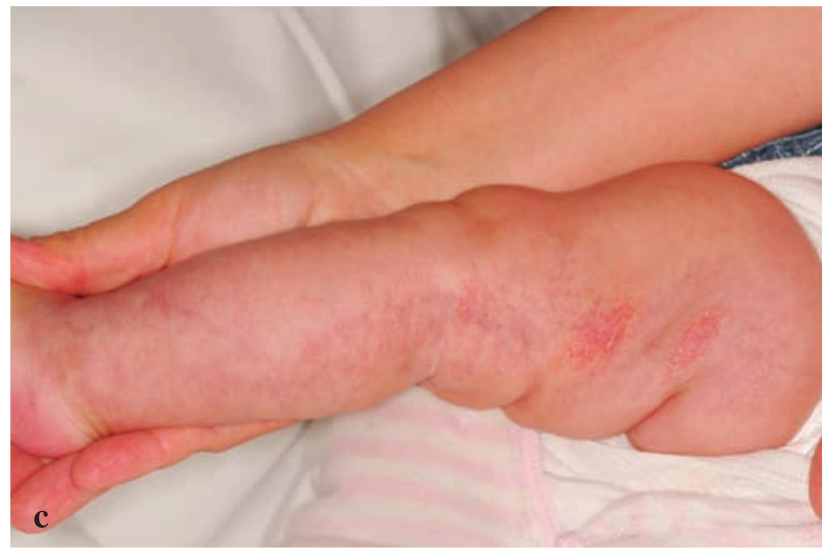

\section{2c. ábra}

A három hónapos korban elvégzett kontroll vizsgálat során a bal comb mediális felszínén 3 darab, ujjbegynyi, erythemás, felszínes hámlást mutató, kissé tömöttebb tapintatú plakk volt észlelhető
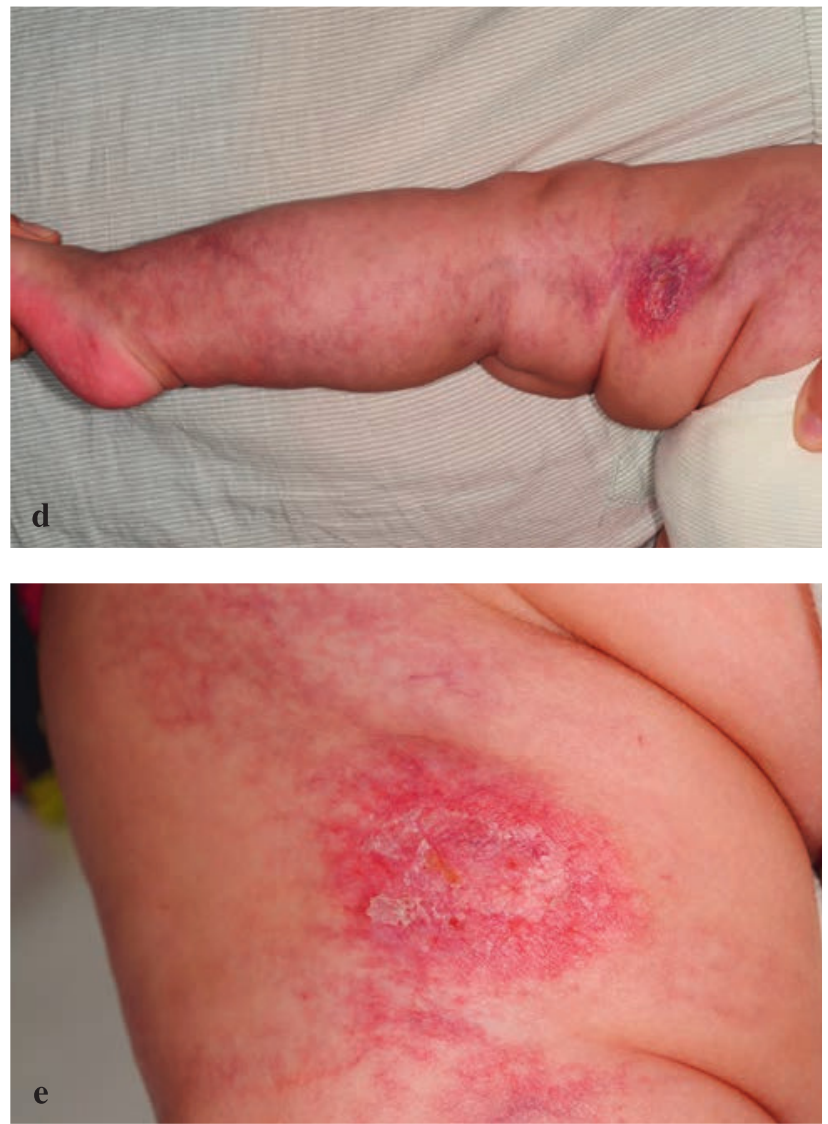

2d-e. ábra

Az öt hónapos életkorban történt ellenőrző vizsgálat során a bal comb hátulsó-mediális felszínén egy érményi, erythemás, kifejezetten telengiectasiás, hámló, minimálisan erodálódott felszínú plakk kialakulását észleltük 
szignifikánsan nem nőtt, perifériás keringése mindvégig rendben volt. A mellkasi röntgen, a koponya- és a hasi ultrahang vizsgálat kóros elváltozást nem igazolt. Kardiológiai konzílium ártalmatlan szívzörejt, záródóban lévő ductus Botallit véleményezett, a congenitalis vitium fennállását kizárta. Egy hetes életkorban, jó általános állapotban került sor hazabocsátására. A gyermek kontrollvizsgálata a Bőrgyógyászati és Allergológiai Klinika Gyermekbőrgyógyászati Szakrendelésén valamint a Gyermekgyógyászati Klinika és Gyermekegészségügyi Központ Kardiológiai Szakrendelésén történik havi rendszerességgel. A három hónapos korban elvégzett kontroll vizsgálat során a bal comb mediális felszínén 3 darab, ujjbegynyi, erythemás, felszínes hámlást mutató, kissé tömöttebb tapintatú plakk kialakulását, az 5 hónapos korban történt ellenôrző vizsgála során a bal comb hátulsó-mediális felszínén egy érményi, erythemás, kifejezetten telengiectasiás, hámló, minimálisan erodálódott felszínú plakk kialakulását észleltük, amelyre lokális emolliens, illetve hámosító kezelést javasoltunk (2.a-e.ábra).

\section{Megbeszélés}

A CMTC igen ritka, sporadikus, congenitalis vascularis malformáció. Első leírója a holland gyermekorvos, Cato van Lohuizen volt 1922-ben, azóta körülbelül 300 esetet írtak le a szakirodalomban, igen változatos leíró nevekkel: congenitalis generalizált phlebectasia, congenitalis phlebectasia, naevus vascularis reticularis, congenitalis livedo, congenitalis livedo reticularis, livedo teleangiectatica, Van Lohuizen-szindróma (1-7). A kórkép előfordulási gyakoriságát illetôen nem állnak rendelkezésre pontos adatok, ennek oka döntően az lehet, hogy az enyhébb, kevésbé kiterjedt esetek nem minden esetben kerülnek felismerésre, diagnosztizálásra; a nemek közötti arány közel azonos $(1,6,8)$. Klinikailag lokalizált, szegmentális vagy generalizált, perzisztáló, kékes-lilás-vöröses színú reticularis rajzolat formájában jelentkezik, leggyakrabban a végtagokon, ritkábban a törzs és az arc területén. Focalis bőratrophiával, egyéb kapilláris malformációval, teleangiectasiával, phlebectasiával társulhat; ritkán bekövetkezhet az érintett bőrterület ulcerációja is $(3,4,6$, 7, 9) (1. táblázat). Viszonylag gyakran megfigyelhetjük az érintett oldali végtag hypo- vagy hypertrophiáját. A tünetek általában már születéskor észlelhetőek, vagy röviddel a születést követóen (3 hónapos kortól két éves korig) jelentkeznek $(3,8,10)$.

A szövettani kép nem specifikus, emiatt a diagnózis döntóen klinikai. Mikroszkópos vizsgálattal a dermisben és a subcutan szövetekben lévő kapillárisok, venulák, vénák, ritkábban a nyirokerek dilatációja, duzzadt endothel sejtek figyelhetőek meg, az erek általában nagyobb méretúek, illetve számuk is nagyobb. Ritkán kapilláris, illetve vénás öblök láthatóak. Az epidermis atrophiája, emellett acanthosis, hyperkeratosis, parakeratosis, erosio és papillomatosis is előfordulhat $(1,4$, 6-9, 11).

Az irodalmi adatok szerint a CMTC viszonylag gyakran társul egyéb rendellenességekkel (20-80\%), ezen elváltozások gyakrabban figyelhetôek meg kiterjedt, generalizált CMTC esetén. Nem tisztázott, hogy valódi együttes előfordulásról van-e szó. Gyakran megfigyelhető testfél- vagy végtag aszimmetria (hypovagy hypertrophia), egyéb vascularis malformáció, végtag defektusok, syndactylia, glaucoma (fóleg amennyiben a CMCT vagy a kapilláris malformáció a periocularis területet érinti). Emellett az egyes eset riportok számos egyéb szervi rendellenesség együttes előfordulásáról számolnak be: mentális retardáció, megkésett pszichomotoros fejlődés, központi idegrendszeri fejlődési rendellenességek, szívfejlődési rendellenességek, aplasia cutis congenita, anus imperforata, hypospadiasis $(3-6,9,10,12)$.

Súlyos központi idegrendszeri elváltozásokkal járó speciális formája az ún. CMTC-macrocephalia szindróma, az újabb nevezéktan szerint kapilláris malformáció-macrochephalia szindróma. Fố diagnosztikus kritériumok közé tartozik a macrocephalia, ventriculomegalia, cerebrális atrophia, corticalis dysplasia, corpus callosum agenesia, reticularis jellegú naevus flammeus, centrofacialis kapilláris malformáció, emellett polidactylia, syndactylia, neonatalis hypotonia, megkésett pszichomotoros fejlődés, hydrocephalus, dysmorphiás arcjegyek, túlnyújható bőr- és ízületek $(7,9,10,13-15)$. Adams-Oliver-szindrómában a CMTC mellett aplasia cutis congenita, illetve koponya- és végtag fejlődési zavarok, szívfejlődési rendellenességek fordulnak elő $(2,9)$.

A CMTC kialakulásának oka nem ismert. Környezeti teratogén ágens szerepe, a vascularis innerváció diszfunkciója, a mesodermális erek fejlődési zavara a korai embrionális fejlődés során, genetikai háttér (inkomplett penetranciával járó autoszómális domináns öröklésmenet, Happle-féle letális gén hypothesis: letális domináns gén fennmaradása mozaicizmus révén) egyaránt feltételezhető $(4,6-8,11,16)$.

Differenciál diagnosztikailag a tünetet el kell különíteni a fiziológiás cutis marmoratatól, amelyet egészséges újszülöttek bőrén észlelhetünk átmenetileg főleg hideg, vagy stressz hatására. A márványszerú rajzolat átmeneti, a melegebb hőmérséklet hatására elmúlik. Az élet első heteiben nehezen lehet elkülöníteni egyéb kapilláris malformációktól (a naevus flammeus assymmetricustól), illetve a Klippel-Trinaunay-szindrómától. A Bockenheimer-féle diffúz

\section{Javasolt CMTC diagnosztikai kritériumok}

(Kienast és Hoeger, 2009)

Major kritériumok (mind a három tünet együttes megléte)

1. Kongenitális retikuláris erythema

2. Lokális melegités hatására is perzisztáló börelváltozás

3. Venectasia hiánya

Minor kritériumok (legalább kettó)

1. A retikuláris erythema spontán halványodása 2 éven belül

2. Teleangiectasia az érintett területen

3. Atrophia az érintett területen

4. Ulceratio az érintett területen

5. Egyéb kapilláris malformáció társulása

\section{1. táblázat}

A CMTC diagnosztikai kritériumai $(12,17)$ 


\section{CMTC differenciál diagnózisa}

- fiziológiás cutis marmorata

- perzisztens cutis marmorata társulása genetikai szindrómákkal

- Down-szindróma,

- Cornelia de Lange-szindróma,

- homocystinuria,

- Divry-Van Bogaert-szindróma

- Reticularis kapilláris malformáció

- generalizált retikuláris kapilláris malformáció

- Bockenheimer-szindróma

- Klippel-Trénaunay-szindróma

- Neonatalis lupus erythematosus

- CMTC-szindrómák

- CMTC-Macrocephalia-szindróma

- Adams-Oliver-szindróma

- CMTC Phakomatosis pigmentovascularis

\section{2. táblázat}

A CMTC differenciáldiagnózisa $(3,9)$

phlebectasia a mélyebb vénákat érintő ritka, progresszív, hamartomatosus malformáció, amely általában születéskor még nem jár klinikai tünetekkel. Nagyméretű vénás sinusoidok alakulnak ki általában egy végtagon; kifejezetten rossz prognózis jellemzi, hiszen gyakori a thrombosis, vérzés, ulceratio, infekció, gangrenosus szövődmények. A homocystinuria, a Down-szindróma, a Cornelia de Lange szindróma, a Divry-Van Bogaert-szindróma is társulhat cutis marmorata-val. A naevus anaemicus, reticularis haemangioma-szindróma, neonatális lupus erythematosus, diffúz phlebectasia, kollagén vascularis betegséggel társuló livedo reticularis ugyancsak felmerülhet differenciáldiagnosztikai problémaként $(3,4,6-9,11,17)$ (2. táblázat).

Összességében a kórkép jó prognózisú, a tünetek az esetek közel 50\%-ában jelentősen halványulnak, regrediálnak az első két életév során a bőr fiziológiás érésének és vastagodásának köszönhetően. Amennyiben perzisztáló, későbbi életkorban kozmetikailag zavaró elváltozásokról van szó, kezelésében festéklézer kezelés megkísérelhető $(4-9,11)$.

A CMTC diagnózis felállítása esetén nagyon fontos a gyermek alapos fizikális és belszervi vizsgálata. A periocularis régióban jelentkező vascularis léziók esetén fontos a szemészeti szakvizsgálat a glaucoma és egyéb szemészeti eltérések kizárása céljából. Minor vagy major fejlődési rendellenesség észlelése esetén további specifikus kivizsgálások szuikségesek a társuló eltérés súlyosságának függvényében. Amennyiben a bőrelváltozáson kívül egyéb eltérést nem tapasztalunk, a gyermekek ellenőrző vizsgálata évente javasolt, legalább 3 éves korig. (3-7, 9, 11, 12).

\section{IRODALOM}

1. Yi G., Oh M.: Cutis marmorata telangiectatica congenita: early detection in two premature infants. Pediatr Dermatol (2000) 17(3), 240-241.

2. Bhargava P., Kuldeep C. M., Mathur N. K.: Cutis marmorata telangiectatica congenita with multiple congenital anomalies. Further clues for a teratogenic cause. Dermatology (1998) 196(3), 368-370.

3. Levy R., Lam J. M.: Cutis marmorata telangiectatica congenita: a mimicker of a common disorder. CMAJ (2011)183(4), E249-E251

4. Devillers A. C., de Waard-van der Spek F. B., Oranje A. P.: Cutis marmorata telangiectatica congenita: clinical features in 35 cases. Arch Dermatol (1999) 135(1), 34-38.

5. Gerritsen M. J., Steijlen P .M., Brunner H. G. és mtsai.: Cutis marmorata telangiectatica congenita: report of 18 cases. Br J Dermatol (2000) 142(2), 366369.

6. Amitai D. B., Fichman S., Merlob P. és mtsai.: Cutis marmorata telangiectatica congenita: clinical findings in 85 patients. Pediatr Dermatol (2000)17(2), 100-104.

7. Flach E., Kellermayer R., Ertl T. és mtsai.: [Cutis marmorata telangiectatica congenita—case report]. Orv Hetil (2007)148(36), 1717-1720.

8. Chatterjee R., Dey S.: Cutis marmorata telangiectatica congenita with skin ulcerations in a new born. Indian J Dermatol (2009) 54(4), 375-377.

9. Garzon M. C., Schweiger E.: Cutis marmorata telangiectatica congenita. Semin Cutan Med Surg (2004) 23(2), 99-106.

10. Hook K. P.: Cutaneous vascular anomalies in the neonatal period. Semin Perinatol (2013) 37(1), 40-48.

11. Soo M.T., Lo K. K., Leung L. C.: Cutis marmorata telangiectatica congenita. Hong Kong Med J (2007) 13(6), 491-492.

12. Kienast A. K., Hoeger P. H.: Cutis marmorata telangiectatica congenita: a prospective study of 27 cases and review of the literature with proposal of diagnostic criteria. Clin Exp Dermatol (2009) 34(3), 319-323.

13. Martinez-Glez V., Romanelli V., Mori M. A. és mtsai.: Macrocephalycapillary malformation: Analysis of 13 patients and review of the diagnostic criteria. Am J Med Genet A (2010) 152A(12), 31013106.

14. Gonzalez M. E., Burk C. J., Barbouth D. S. és mtsai.: Macrocephaly-capillary malformation: a report of three cases and review of the literature. Pediatr Dermatol (2009) 26(3), 342-346.

15. Rekate H. L.: Macrocephaly-cutis marmorata telangiectatica congenita. J Neurosurg (2007) 106(4 Suppl), 292-293.

16. Danarti R., Happle R., Konig A.: Paradominant inheritance may explain familial occurrence of Cutis marmorata telangiectatica congenita. Dermatology (2001) 203(3), 208-211.

17. Matic A., Pricic S., Matic M. és mtsai.: Cutis marmorata telangiectatica congenita in a preterm newborn - Case report and literature review. Iran Red Crescent Med J (2012) 14(9), 578-583.

Érkezett: 2014. 07. 21.

Közlésre elfogadva: 2014. 08. 01. 